Ryan, F. J. (1952). J. gen. Microbiol. 7, 69-88

\title{
Adaptation to use Lactose in Escherichia Coli
}

\author{
By F. J. RYAN* \\ Service de Physiologie Microbienne, Institut Pasteur, Paris
}

SUMMARY: The adaptation of a genetically deficient strain of Escherichia coli (Bacterium coli) to the utilization of lactose was shown to involve overgrowth of the population by a small number of mutants. The rate of mutation to lactose utilization is about $2 \times 10^{-7}$ per bacterium per generation. This rate is not influenced by lactose or a series of substances related to that sugar. The distribution of these mutants among different cultures is in agreement with that expected on the basis of random mutation. These results are discussed in connexion with the theories of Hinshelwood on bacterial adaptation, and in relation to the problem of specifically induced mutation.

Bacteria are remarkably plastic in their ability to undergo satisfactory adjustments in new environments. These adjustments are adaptations in the original biological sense of the word whether they are inherited or not, and irrespective of the underlying mechanisms.

The adaptation of a bacterium to grow in one environment may be transmitted to its progeny for a few generations in a different environment, but such an adaptation would be considered to involve a genetic change only if the intracellular factors responsible for the adapted character could be shown to have multiplied in the course of these generations. Thus, in the case of those adaptive enzymes that are simply diluted to the unadapted level during bacterial division in the absence of their peculiar substrates, the adaptation does not involve a genetic change. On the other hand, when the adaptation involves the selective overgrowth of a population by organisms possessing a mutation in a chromosomal or non-chromosomal gene, it may be inherited in another environment because of the multiplication of the mutated factor.

Nevertheless, the criterion of stability alone does not allow a distinction between genetic and non-genetic adaptations because gene mutations are generally reversible. Nor need the distinction be as clear-cut as first indicated. Rather, it is preferable to ask more specific questions about the nature of the adaptive mechanism. First, it is important to know whether an adaptation occurring in a population of bacteria involves all members of the population or whether there is selective overgrowth by a few unusual members. Further, it is necessary to know whether the change has been induced by the new environment or whether it may occur in another, or whether both possibilities exist.

For example, Escherichia coli (Bacterium coli) strain lac ${ }^{+}$possessing the inherited ability to grow on lactose is unable to do so at a maximum rate until it has been exposed to the sugar for some time (Monod \& Audureau, 1946). This adaptation is due to the increased synthesis of the enzyme lactase in cells exposed to lactose (Cohn \& Monod, 1951). Other sugars and glycosides may

* Present address: Department of Zoology, Columbia University, New York. 
also induce lactase synthesis, but it appears that the possession of an unsubstituted galactoside radical is an essential but insufficient condition (Monod, Cohen-Bazire \& Cohn, 1951). The lactase formed in one cell may be transmitted to its progeny, but since the amount of enzyme increases only in the presence of an inducing substance the adaptation in lactase synthesis is not due to a genetic change.

It remains a question to what extent genetic factors operate in this sort of adaptation. Lac ${ }^{-}$bacteria, from which the $\mathrm{lac}^{+}$strain had been obtained by mutation, do not increase their content of lactase in the presence of lactose during a period in which lac $^{+}$bacteria would have become completely adapted. Thus it would seem that the presence of a gene peculiar to lac ${ }^{+}$organisms is necessary for the adaptation discussed above. Yet a culture begun with lac ${ }^{-}$ bacteria will, after a long lag period, eventually be transformed into one indistinguishable from $\mathrm{lac}^{+}$. The present paper presents an analysis of the nature of this adaptive response of lac bacteria. Two main questions are examined. First, what percentage of the population is involved in the change; and, secondly, is the initial change in this segment independent of the presence of lactose or related compounds? An examination of the first question has already been made for other adaptations (Fildes \& Whitaker, 1948; Ryan \& Schneider, 1949; Jackson \& Hinshelwood, 1949; Barer, 1950) and interpretations have varied for reasons that will become evident. Luria \& Delbrück (1943) have developed a method for determining whether the change in the individual bacteria is provoked by the testing substance, but this method has been criticized by Eriksen (1949) and Hinshelwood (1950). In the present paper these criticisms have been taken into account.

\section{MATERIALS AND METHODS}

Strain. The organism used in these studies was a strain of Esch. coli ML which is able to grow with glucose, maltose, or galactose as sole carbon source in a defined medium devoid of added growth factors. It is, however, unable to use lactose (Monod \& Audureau, 1946). This strain is known not to undergo recombination. The mutant strain requiring tryptophan was secured by Monod after ultraviolet irradiation.

The study reported in this paper was concerned with the change from inability to grow on lactose ( $\operatorname{lac}^{-}$bacteria) to the ability to utilize this sugar (lac ${ }^{+}$bacteria). Monod \& Cohn (1952) have described a chemical basis for the difference between the two states. When both strains are grown in the absence of lactose they possess only a trace of lactase and are indistinguishable on this basis and in terms of amounts and rates of growth. Upon exposure to lactose, $\mathrm{lac}^{+}$bacteria increase their lactase content some hundreds of fold in a few hours while lac ${ }^{-}$bacteria are unable to do this, increasing their lactase content little if at all.

Stocks and inocula. Upon receipt all cultures were plated out on a nutrient agar containing beef extract and peptone. Single colonies were picked on to nutrient agar slopes on which also the organisms were subcultured every few months. The characters differentiating one strain from the other were verified 
initially as was the phage-resistance pattern characteristic of all ML strains used. Inocula were prepared by transferring a small amount of surface growth from an agar slope into $5 \mathrm{ml}$. of defined medium supplemented with $5 \cdot 6 \times 10^{-3} \mathrm{M}$ $(0.2 \%, \mathrm{w} / \mathrm{v})$ maltose (and $20 \mu \mathrm{g}$. DL-tryptophan $/ \mathrm{ml}$. when necessary). The test-tubes containing the inocula were shaken in an inclined position at $37^{\circ}$ for about $12 \mathrm{hr}$. after which time there were about $3 \times 10^{9}$ bacteria $/ \mathrm{ml}$. in a stationary phase brought about by sugar exhaustion. In the case of tryptophan-requiring bacteria the inocula were washed by two centrifugations and resuspensions in sterile water to remove traces of unused tryptophan.

Defined medium and sugars. The basal medium contained, per litre of water: $13 \cdot 6$ g. $\mathrm{KH}_{2} \mathrm{PO}_{4} ; 2 \cdot 0$ g. $\left(\mathrm{NH}_{4}\right)_{2} \mathrm{SO}_{4} ; 0 \cdot 2$ g. $\mathrm{MgSO}_{4} .7 \mathrm{H}_{2} \mathrm{O} ; 0.01$ g. $\mathrm{CaCl}_{2} ; 0.0005$ g. $\mathrm{FeSO}_{4} .7 \mathrm{H}_{2} \mathrm{O}$; and enough $(c .8 \mathrm{ml}$.) $10 \mathrm{~N}-\mathrm{KOH}$ to bring the solution to $\mathrm{pH} \mathbf{7} \cdot 4$. The sugars used were passed through Pyrex UF glass filters for sterilization and were then added (usually in a concentration of $0.2 \%, w / v$ ) to the autoclaved medium. One sample of Pfanstiehl $\beta$-lactose was recrystallized from water at room temperature three times. The other chemicals used in these experiments have been described by Monod et al. (1951).

Defined medium was usually solidified by the addition of $2 \%(w / v)$ washed agar. In this case $4 \%$ agar in water was autoclaved separately and then mixed with an equal volume of basal medium of double strength. In some instances the medium was solidified with 5 or $8 \%(\mathrm{w} / \mathrm{v})$ silica gel. The proper amount of $\mathrm{Na}$ silicate solution, sterilized by ultraviolet light, was mixed in a Petri dish with sterile basal medium and sugar and neutralized with sterile $2 \mathrm{~N}-\mathrm{HCl}$. The bacterial suspension was then mixed and the plate allowed to set, a process that usually took place within $15 \mathrm{~min}$. In some instances the medium and bacteria were added to ultraviolet sterilized silica gel plates prepared and washed free of $\mathrm{NaCl}$ by a method kindly demonstrated by Dr Hélène Winogradsky.

Culture conditions. Cultures were always shaken in inclined test tubes at a rate providing maximum aeration at $37^{\circ}$. When necessary, growth was followed by turbidimetric measurements in a Meunier densitometer, by the use of specially constructed T-shaped tubes (Monod et al. 1951). With this densitometer changes in density equivalent to about $10^{6} \mathrm{bacteria} / \mathrm{ml}$. in the exponential phase of growth can be detected and optical density is directly proportional to bacterial number up to concentrations of about $10^{8}$ bacteria $/ \mathrm{ml}$.

\section{Enumeration and characterization of $\mathrm{lac}^{+}$and lac- bacteria}

Total bacterial counts were made of organisms stained with methylene blue in a haemocytometer. Viable counts of liquid cultures were made by plating appropriate dilutions, made in sterile water, into maltose agar (a bottom layer of agar was always present in the plates before the bacterial suspension was introduced). After $36 \mathrm{hr}$. at $37^{\circ}$, well-formed colonies could be counted. Counts of the number of bacteria in microcolonies, whose diameter had been determined with a micrometer ocular, were made by isolating whole colonies on small blocks of agar by means of the spatulate tip of an inoculation needle under a dissecting microscope, and transferring to $1 \mathrm{ml}$. lots of sterile water. 
After suspension and appropriate dilutions the bacteria from the microcolonies were plated into maltose agar. Independent estimates of the number of bacteria in microcolonies of different diameter were made for all of the conditions tested.

When streaked or plated on the surface of eosine methylene blue (EMB) agar or Endo agar $\mathrm{lac}^{+}$bacteria form blue or red colonies, while the colonies formed by lac bacteria are nearly white in colour. After 1 or 2 days the surfaces of $\mathrm{lac}^{-}$colonies become spotted with coloured papillae that consist of lac $^{+}$bacteria (Massini, 1907). Lac ${ }^{-}$bacteria plated in EMB or Endo agar form colonies which appear light rose after one day, but later they gradually become more intensely coloured. On the other hand, under the same conditions $\mathrm{lac}^{+}$bacteria form colonies which are deeply coloured at the outset.

By the use of these indicator agars it is possible on a single plate to distinguish a few bacteria of one type in the presence of the other provided that their frequency is not much less than $10^{-3}$. Direct plating of about 400 bacteria on the surface of a number of EMB plates showed that in $\mathrm{lac}^{-}$cultures the frequency of $\mathrm{lac}^{+}$bacteria was probably $<7 \times 10^{-5}$, and that $\mathrm{lac}^{+}$cultures probably contained $<10^{-4} \mathrm{lac}^{-}$bacteria. This method is, however, limited by the fact that the bacteria existing as the major component are not prevented from forming good sized colonies. It has not yet been possible to measure smaller frequencies of $\mathrm{lac}^{-}$bacteria, for attempts to concentrate them by the use of penicillin have failed, for a reason that will become evident (see Results).

It is possible, however, to screen for lac $^{+}$bacteria present in very small frequencies in lac ${ }^{-}$populations by a special method that takes advantages of the differential ability of the two types to grow on lactose agar. This involves plating a culture whose growth has stopped because of the exhaustion of sugar on to the surface of thick lactose agar plates that have been dried by storage at $37^{\circ}$ for 2 days. Between $0 \cdot 1$ and $0.3 \mathrm{ml}$. bacterial suspension is placed on the surface of the agar and spread with a sterile glass rod until all the liquid has been absorbed and the surface is once again dry. After between 16 and $18 \mathrm{hr}$. at $37^{\circ}$ the $\mathrm{lac}^{+}$bacteria have formed colonies easily recognizable at a $6.3 \times$ magnification under a dissecting microscope. Because of the importance for this analysis of differential viable counts of $\mathrm{lac}^{-}$and $\mathrm{lac}^{+}$bacteria in the same culture, the reliability of this method will be examined in some detail under Results.

\section{RESULTS}

\section{Growth of lac ${ }^{-}$bacteria on lactose}

Populations of lac bacteria, when serially transferred in defined medium containing maltose, retain their lac ${ }^{-}$character. On the other hand, when lac ${ }^{-}$bacteria are inoculated into medium containing lactose they form a culture which is $\mathrm{lac}^{+}$in character. Thenceforth, when such a culture is carried in the absence of lactose for more than 100 generations, it retains that character. To test whether this result was arrived at by a change in all of the bacteria present or by the selection of a few mutants in the inoculum, single lac ${ }^{-}$ bacteria were inoculated into medium containing $1 \cdot 6 \times 10^{-3} \mathrm{M}$ lactose. This 
inoculation was achieved by introducing an average of $0.90 \mathrm{lac}^{-}$bacteria grown on maltose into 50 separate $10 \mathrm{ml}$. cultures. Use of the Poisson formulation allows the calculation that 18 cultures would be expected to have received one bacterium, and 12 cultures more than one. It was found that 26 cultures showed visible turbidity after about $50 \mathrm{hr}$., demonstrating that single lac bacteria were eventually able to form populations of bacteria that grow on lactose. The same conclusion may be drawn from the fact that all lac bacteria spread on the surface of agar containing $1 \cdot 6 \times 10^{-3} \mathrm{M}$ lactose will form lac ${ }^{+}$ colonies in a matter of days. This would indicate that every lac bacterium is able to adapt to grow on lactose, were it not for the possibility that the lac bacteria might first form micropopulations in lactose medium, due to the utilization of other substances present, and subsequently mutate to the lac ${ }^{+}$ condition. In fact, this is what occurs.

\section{Growth of lac bacteria in the absence of added sugar}

Each lac ${ }^{-}$bacterium grown to sugar exhaustion on maltose, when plated on the surface of lactose agar, will form a circular colony of uniform depth and homogeneous appearance which grows slowly $(c .0 .06$ doublings $/ \mathrm{hr}$.) as shown in Fig. 1. The number of cells/colony is directly proportional to the area, indicating that such colonies grow on the surface of agar in a fashion approximating flat cylinders with continually increasing circumferences. When such colonies at any stage of growth are streaked on to an indicator agar they give characteristic lac reactions. Eventually, however, local thickenings or papillae appear on the surfaces of these colonies, and when this occurs early enough the papillae overgrow the old colony to form a superimposed one that increases in size at a rapid rate (Monod \& Audureau, 1946). Inoculation of such papillae, or of superimposed colonies, to indicator agar demonstrates their lac $^{+}$character. It would appear as though the growth of the lac ${ }^{-}$ microcolony resulted eventually in populations so large as to make mutation to lac ${ }^{+}$a likely event. The quantitative examination of this possibility will be deferred until later in this paper.

The original growth of the lac ${ }^{-}$microcolony might be due in small part to the slow utilization of lactose or of impurities not removed by recrystallization. A larger part is due to other carbon sources, since lac ${ }^{-}$bacteria on agar devoid of lactose form microcolonies almost as large as on lactose agar. When the agar has been carefully washed the microcolonies formed are somewhat smaller. Microcolonies are formed even on silica gels. They grow to a larger size as satellites around lac $^{+}$colonies, but their presence even in the absence of the latter indicates that the medium forming the base of the gel contains some carbon source.

This possibility was examined by inoculating about $2 \times 10^{3} \mathrm{lac}^{-}$bacteria into $10 \mathrm{ml}$. liquid medium with and without lactose. From time to time during incubation at $37^{\circ}$ samples were taken and plated in Endo agar. The growth curves obtained are shown in Fig. 2. Serial transfer from one culture without lactose to another resulted each time in similar amounts of growth, suggesting that growth was due to a limited amount of carbon source contaminating the 
medium. In order to locate the source of this contamination water twice distilled over alkaline permanganate was used exclusively, all glassware was carefully cleaned in chromic-sulphuric acid cleaning solution and rinsed in this twice distilled water, care was taken to avoid contact with cotton by the use of tin caps for tubes and flasks, and all media were sterilized by filtration through a Pyrex UF glass filter. Nevertheless, similar results were obtained. Apparently the contaminating carbon source resides in the salts employed. It allows the growth of $c .8 \times 10^{6}$ bacteria $/ \mathrm{ml}$. and is the equivalent of $c .4 \mu \mathrm{g}$. sugar $/ \mathrm{ml}$. This would involve a contamination of 2 parts $/ 1000$ of salt, a possibility that seems not out of the question.

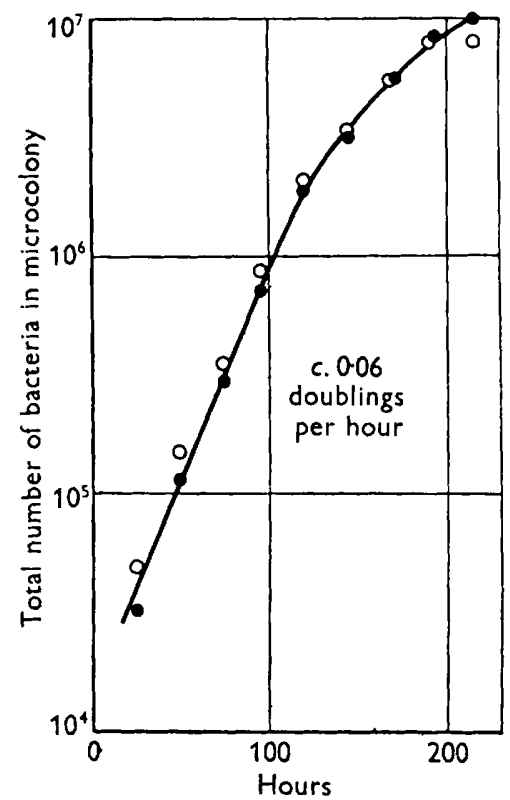

Fig. 1

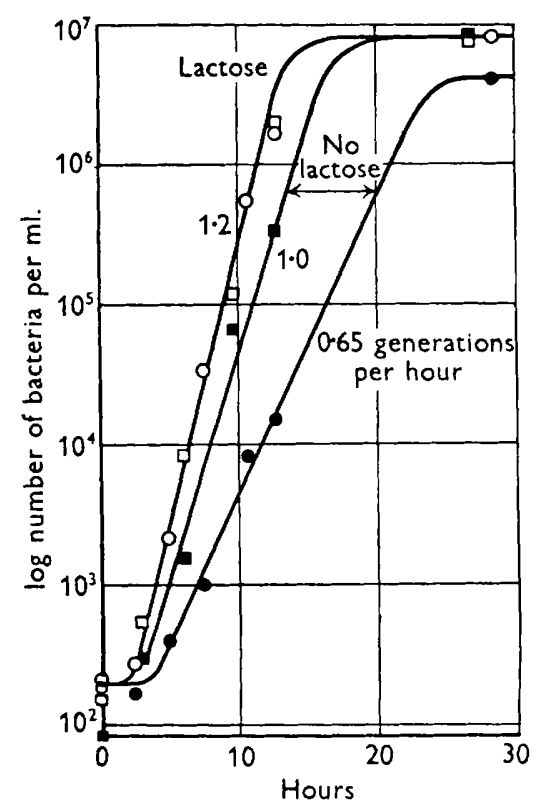

Fig. 2

Fig. 1. The growth of lac $^{-}$bacteria in a microcolony as determined by measuring the increase in diameter of eight colonies on $1.6 \times 10^{-4} \mathrm{M}$ lactose agar (-O-O- ) and eight colonies on agar to which no carbon source has been added (- - The colony diameters were converted into numbers of bacteria by the use of the relationship between diameter and bacterial number obtained by plating out microcolonies of different size from both types of agar.

Fig. 2. The growth of $\mathrm{lac}^{-}$bacteria in defined liquid medium with $1 \cdot 6 \times 10^{-3} \mathrm{M}$ lactose $(-\square-\square-$ and $-\mathrm{O}-\mathrm{O}-$ ) and without lactose $(-\square-\square-$ and $-0-0-$ ). The circles represent data obtained when routine procedures were used; the squares, when special precautions were taken to decrease the amount of contaminating carbon source in the defined medium.

\section{Critique of the method for characterizing $\mathrm{lac}^{+}$bacteria}

In view of the fact that $\mathrm{lac}^{-}$bacteria in lactose medium eventually do give rise to populations which grow to completion it is necessary to specify more precisely, for operational reasons, the difference between lac ${ }^{-}$and $\mathrm{lac}^{+}$bacteria in their growth on lactose. By definition a lac ${ }^{+}$strain consists of bacteria 
which, when heavily suspended in water and placed on the surface of agar containing defined medium and $6 \cdot 4 \times 10^{-4} \mathrm{M}(0 \cdot 2 \% \mathrm{w} / \mathrm{v})$ lactose, form a heavy layer of growth in $24 \mathrm{hr}$. at $37^{\circ}$. $\mathrm{Lac}^{-}$bacteria, on the contrary, may form only the slightest film of background growth which, after a matter of days, becomes spotted with papillae containing $\operatorname{lac}^{+}$bacteria. When such a criterion is used to identify lac ${ }^{-}$bacteria it is found completely correlated with the formation of white to pink growth on or in Endo or EMB agar, with a long delay in the onset of growth upon inoculation into liquid medium containing lactose, and with the inability to form large concentrations of lactase within a few hours after exposure to lactose.

Despite the ability to distinguish $\mathrm{lac}^{+}$clearly from $\mathrm{lac}^{-}$bacteria upon analysis, it is still difficult to detect accurately a few $\mathrm{lac}^{+}$bacteria among many $\mathrm{lac}^{-}$. The limitations of indicator agar have already been mentioned. Furthermore, when a mixed population of $\mathrm{lac}^{+}$and $\mathrm{lac}^{-}$bacteria, grown to a sugarlimited stationary phase, is plated into lactose agar, some lac ${ }^{+}$colonies, surrounded by lac satellites, are visible to the naked eye after 1 day. With increasing time the number of $\mathrm{lac}^{+}$colonies increases. Since tenfold dilutions do not result in tenfold decreases in number of $\mathrm{lac}^{+}$colonies, we can be sure that at least some $\mathrm{lac}^{+}$colonies have resulted from the growth of $\mathrm{lac}^{+}$bacteria formed from lac ${ }^{-}$organisms in the plate. Similar results are obtained when the mixture is plated on the surface of lactose agar.

Since it is necessary to know the number of $\mathrm{Iac}^{+}$bacteria present in the culture that was plated, uninfluenced by the number of $\mathrm{lac}^{+}$organisms that arise afterwards, the following experiment was performed. A series of tenfold dilutions of a sugar-starved lac culture, with and without the addition of a fixed number of $\mathrm{lac}^{+}$bacteria, were spread on the surface of lactose agar and the number of $\operatorname{lac}^{+}$colonies was counted after 1 and 2 days. The results are shown in Table 1 . It will be observed that after 1 and 2 days tenfold dilutions did not give tenfold decreases in the number of $\mathrm{lac}^{+}$colonies. When, however, the number of colonies present is plotted as a function of time and a straight line drawn through the points for a given condition and extrapolated toward zero time, tenfold decreases in the numbers of $\mathrm{lac}^{+}$colonies are found at about $18 \mathrm{hr}$. If the number of $\mathrm{lac}^{+}$colonies found at this time represents the numbers of $\mathrm{lac}^{+}$bacteria in the culture that was plated, then on the plates to which a fixed number of $\mathrm{lac}^{+}$bacteria had been added there should be an equivalent excess of $\mathrm{lac}^{+}$colonies. That this is so is shown in Table 1. Similar results were obtained on silica gels.

Rather than rely upon an extrapolation procedure the number of lac ${ }^{+}$ colonies existing on the plates at $18 \mathrm{hr}$. was counted directly under a dissecting microscope. As is shown in Table 2, tenfold decreases were found and the expected number of added $\mathrm{lac}^{+}$bacteria recovered as colonies. This procedure, of demonstrated reliability, was therefore adopted as routine. The number of $\mathrm{lac}^{+}$colonies was usually counted about $16 \mathrm{hr}$. after plating. At this time there is a clear distinction between the lac ${ }^{-}$microcolonies or background growth and the $\operatorname{lac}^{+}$colonies which are then between 0.3 and $0.4 \mathrm{~mm}$. in diameter. There are always, however, a few colonies of intermediate size 
which represent the growth of the first lac ${ }^{+}$bacteria formed on the plate, but their enumeration can be easily avoided. When twenty-five $0.1 \mathrm{ml}$. samples from the same $0.5 \times 10^{-2}$ dilution of a lac ${ }^{-}$culture were spread on lactose agar and the lac $^{+}$colonies counted after $16 \mathrm{hr}$., an average number of $15 \cdot 4$ with a variance of 18.7 was obtained. The probability of such a sample being taken from a homogeneous population is $0 \cdot 15$. During routine use of this method of counting $\operatorname{lac}^{+}$bacteria, dilutions were studied from time to time to confirm its validity.

Table 1. The number of lac ${ }^{+}$bacteria determined by extrapolation

\begin{tabular}{|c|c|c|c|c|}
\hline \multirow[b]{2}{*}{$\begin{array}{l}\text { Dilution } \\
\text { of lac } \\
\text { culture }\end{array}$} & \multicolumn{3}{|c|}{ No. of $\mathrm{lac}^{+}$colonies } & \multirow{2}{*}{$\begin{array}{c}\text { No. of excess lac } \\
\text { on plates to which } \\
\text { lac bacteria had } \\
\text { been added } \\
\text { (c. } 227 \mathrm{lac}^{+} \text {added) }\end{array}$} \\
\hline & $\begin{array}{c}\text { By } \\
\text { extrapolation } \\
(18 \mathrm{hr} .)\end{array}$ & $\begin{array}{c}\text { By } \\
\text { direct count } \\
(23 \mathrm{hr} .)\end{array}$ & $\begin{array}{c}\text { By } \\
\text { direct count } \\
(46 \mathrm{hr} .)\end{array}$ & \\
\hline $10^{-3}$ & 14 & 62 & 253 & 210 \\
\hline $10^{-5}$ & 0 & 0 & 160 & 240 \\
\hline & $(16 \mathrm{hr})$. & $(22.5 \mathrm{hr})$. & $(47.5 \mathrm{hr})$. & (c. $320 \mathrm{lac}^{+}$added) \\
\hline $10^{-1}$ & 683 & 733 & 970 & 379 \\
\hline $10^{-2}$ & 85 & 145 & 445 & 230 \\
\hline $10^{-3}$ & 6 & 66 & 355 & 212 \\
\hline $10^{-4}$ & 0 & 5 & 216 & 251 \\
\hline
\end{tabular}

Table 2. The number of lac ${ }^{+}$bacteria determined by early count

\begin{tabular}{|c|c|c|c|}
\hline \multirow{2}{*}{$\begin{array}{l}\text { Dilution } \\
\text { of lac } \\
\text { culture }\end{array}$} & \multicolumn{2}{|c|}{ No. of lac ${ }^{+}$colonies } & \multirow{2}{*}{$\begin{array}{c}\text { No. of excess lac } \\
\text { on plates to which } \\
\text { lac }{ }^{+} \text {bacteria had } \\
\text { been added } \\
\text { (c. } 22 \mathrm{lac}^{+} \text {added) }\end{array}$} \\
\hline & (18 hr.) & (39 hr.) & \\
\hline $10^{-2}$ & 284 & 536 & 29 \\
\hline $10^{-3}$ & 21 & 315 & 20 \\
\hline $10^{-4}$ & 7 & 288 & 11 \\
\hline \multirow[t]{2}{*}{$10^{-5}$} & 0 & 99 & 17 \\
\hline & $(18 \mathrm{hr})$. & (36 hr.) & (c. $65 \mathrm{lac}^{+}$added $)$ \\
\hline $10^{-2}$ & 579 & 733 & - \\
\hline $10^{-3}$ & 63 & 274 & 55 \\
\hline $10^{-4}$ & 6 & 160 & 49 \\
\hline $10^{-5}$ & 1 & 133 & 47 \\
\hline
\end{tabular}

The behaviour of non-growing lac ${ }^{-}$bacteria in the presence of lactose

Although the effects of the background growth of lac ${ }^{-}$bacteria can be avoided in the enumeration of lac $^{+}$organisms it remains troublesome for experiments designed to determine the fraction of the population undergoing the change. In liquid cultures it gives a turbidity that is just under the level of visibility to the naked eye. If only one mutant arose during the growth to $10^{8}$ bacteria/10 ml. (just visible turbidity), this mutant would be expected to use whatever lactose was present and overgrow to form a lac ${ }^{+}$culture. For example, in the experiments shown in Fig. 2, at the time of the last sampling, about $2.5 \%$ of the population in the lactose medium consisted of lac ${ }^{+}$bacteria as judged by their reaction in Endo agar. On the other hand, less than $10^{-5}$ of the bacteria present in the medium without lactose were lac ${ }^{+}$. This could be 
interpreted as due to incomplete overgrowth by a small number of lac ${ }^{+}$ mutants or due to the incomplete transformation of the $\mathrm{lac}^{-}$bacteria, all of whom would eventually become $\mathrm{lac}^{+}$in the presence of lactose. One could eliminate the difficulties introduced through residual growth by further purifying the salts, by cleaning the medium of carbon source by bacterial growth with subsequent filtration, or by using bacteria whose growth is limited by the absence of some substance other than a carbon source.

When lac $\mathrm{c}^{-}$bacteria unable to synthesize tryptophan $\left(\mathrm{lac}^{-} \mathrm{t}^{-}\right)$are inoculated. into $10 \mathrm{ml}$. of medium containing lactose but devoid of tryptophan, no visible growth ensues even after 7 days (Table 3 ). In some instances populations as large as $10^{5}$ bacteria/ml. developed, presumably due to contaminating traces of tryptophan, while in other instances the number of bacteria present remained essentially constant. In all, about $10^{4}$ bacteria were tested for their lac ${ }^{-}$ character after exposure to lactose for periods varying between 1 and 7 days. The fact that, despite a certain amount of growth in lactose, none had been changed to a lac ${ }^{+}$condition suggests that the adaptation of $\mathrm{lac}^{-}$bacteria to lactose, which would occur if the population became somewhat larger, does not involve a large fraction of the organisms present. A similar experiment allowed the same conclusion. When $5 \times 10^{3} \mathrm{Iac}^{-} \mathrm{t}^{-}$bacteria were distributed on the surface of agar plates containing between $1.6 \times 10^{5}$ and $1.6 \times 10^{3} \mathrm{M}$ lactose and layered with Endo agar after periods varying between 1 and 6 days, none became $\mathrm{lac}^{+}$in character.

Table 3. The effect of lactose on lac $t^{-}$bacteria

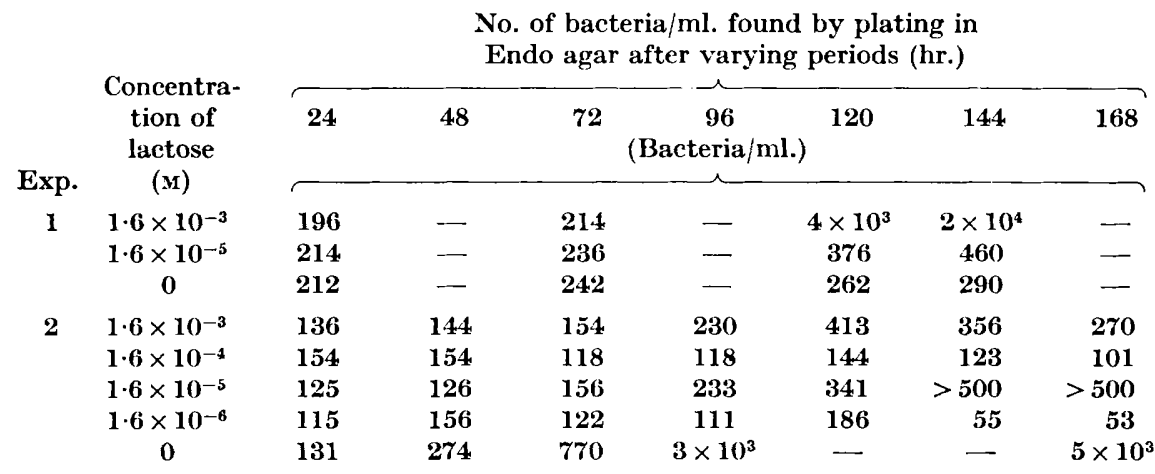

Apparently under these conditions the adaptation of $\mathrm{lac}^{-}$bacteria in the presence of lactose involves very few members of the population. It could conceivably be argued, however, that in the presence of limiting concentrations of tryptophan (or of any other substance) the enzyme syntheses required to make all or most of the cells lac ${ }^{+}$cannot occur. To take this possibility into account it is necessary to examine by some other method the question of whether the change to lac ${ }^{+}$occurs only in special members of the population. This question will be further considered under Discussion. 
The effect of lactose on the rate of mutation from the lac ${ }^{-}$to the $\mathrm{lac}^{+}$condition

The bacteria in a lac ${ }^{-}$population that are capable of utilizing lactose for growth may have an origin that is independent of, or dependent upon, that sugar. If the latter were true the chance that a lac $^{-}$bacterium would be converted into a lac ${ }^{+}$would be different in the presence and absence of lactose. There are several ways to determine the magnitude of this chance.

Advantage may be taken of the fact that lac $^{-}$microcolonies form lac ${ }^{+}$ papillae. Since the papillae are usually well separated on the colony surface each one must represent at least one independently mutated lac ${ }^{-}$bacterium. Because of the delay between mutation and the formation of a visible papilla, and because, due to their location, some mutant bacteria may be unable to manifest their presence, the papilla count will always be lower than the number of mutations. Hence the mutation rate calculated by this method is a minimum estimate. In one experiment, in the presence of $6 \times 10^{-4} \mathrm{M}$ lactose an average of 3.9 papillae was found among 70 microcolonies whose average bacterial content was $1.7 \times 10^{7}$. The total number of bacterial generations involved in the formation of a microcolony of this size is $\frac{1 \cdot 7 \times 10^{7}}{\ln 2}$ and this divided into 3.9 gives $1.6 \times 10^{-7}$ as the chance per generation that any lac ${ }^{-}$ bacterium will mutate to a lac $^{+}$.

The same rate of change is found when, by the Poisson formulation, the average number of papillae is calculated from the number of colonies without papillae. It is first necessary to show that the papillae are distributed at random among lac ${ }^{-}$colonies. For this purpose Endo agar and agar containing $1.3 \times 10^{-3} \mathrm{MD}$-galactose and $6.4 \times 10^{-4} \mathrm{M}$ lactose were chosen since they supported considerable growth of the lac ${ }^{-}$bacteria, thus allowing a reasonable number of papillae to form. In measuring this distribution special care was taken to use agar plates of uniform thickness and to consider only wellformed separated colonies of the same size. The results are shown in Table 4. The evidence is consistent with the hypothesis that papillae (and hence the mutations they represent) are distributed at random among the colonies.

Table 4. The distribution of mutant papillae on colony surfaces

\begin{tabular}{|c|c|c|c|c|c|}
\hline Medium & $\begin{array}{l}\text { Colony } \\
\text { diameter } \\
(\mathrm{mm} .)\end{array}$ & $\begin{array}{l}\text { No. of } \\
\text { colonies }\end{array}$ & $\begin{array}{l}\text { Average } \\
\text { no. of } \\
\text { papillae/ } \\
\text { colony }\end{array}$ & $\begin{array}{l}\text { Probability } \\
\text { of } \\
\text { homogeneity }\end{array}$ & $\begin{array}{l}\text { Probability } \\
\text { of drawing } \\
\text { a similar } \\
\text { sample from } \\
\text { Poisson } \\
\text { distribution }\end{array}$ \\
\hline Endo agar & $3 \cdot 4$ & 35 & $10 \cdot 0$ & $0 \cdot 3$ & 0.5 \\
\hline $\begin{array}{l}\text { Lactose-galactose } \\
\text { agar }\end{array}$ & $\begin{array}{l}2 \cdot 2 \\
2 \cdot 4 \\
2 \cdot 5\end{array}$ & $\begin{array}{l}55 \\
34 \\
20\end{array}$ & $\begin{array}{l}2 \cdot 0 \\
2 \cdot 9 \\
3 \cdot 0\end{array}$ & $\begin{array}{c}\gg 0.05 \\
0.3 \\
0.5\end{array}$ & $\begin{array}{l}0 \cdot 4 \\
0 \cdot 7 \\
0 \cdot 07\end{array}$ \\
\hline
\end{tabular}

Table 5 summarizes the mutation rates obtained by the calculation by the Poisson method of the number of papillae among about $10^{4}$ microcolonies and shows that the rate of change is independent of the concentration of lactose 
used and of the size of the colonies in which the change occurs. The data on which this table is based are homogeneous by $\chi^{2}$ test $(P=\gg 0.05)$ and give an average chance of change of $1 \cdot 6 \times 10^{-7} /$ bacterium/generation in the presence of lactose.

Table 5. The rate of mutation to lac $^{+} /$generation of lac ${ }^{-}$bacteria as a function of the concentration of lactose and the size of the microcolony

$\begin{gathered}\text { Concentration } \\ \text { of lactose } \\ (M)\end{gathered}$
$1 \cdot 6 \times 10^{-3}$
$8 \cdot 0 \times 10^{-4}$
$1 \cdot 6 \times 10^{-4}$
$1 \cdot 3 \times 10^{-4}$
$3.0 \times 10^{-5}$
$1.6 \times 10^{-5}$

$\begin{gathered}\text { Rate of } \\ \text { change }\end{gathered}$
$2.0 \times 10^{-7}$
$1.1 \times 10^{-7}$
$1.4 \times 10^{-7}$
$0.94 \times 10^{-7}$
$1.1 \times 10^{-7}$
$1.8 \times 10^{-7}$

\begin{tabular}{|c|}
\hline in \\
\hline $\begin{array}{l}6.4-9.9 \times 10^{4} \\
1.0-4.9 \times 10^{5}\end{array}$ \\
\hline $5 \cdot 0-9.9 \times 10^{5}$ \\
\hline $\begin{array}{l}1.0-4.9 \times 10^{8} \\
5.0-8.6 \times 10^{8}\end{array}$ \\
\hline
\end{tabular}

Rate of change

$1.3 \times 10^{-7}$

$2 \cdot 3 \times 10^{-7}$

$2 \cdot 0 \times 10^{-7}$

$1.3 \times 10^{-9}$

$1 \cdot 1 \times 10^{-7}$

It may seem surprising that the minimum estimate of the rate of mutation does not increase as the rate of growth of the colony slows down for this should allow a relatively faster rate of papilla formation in comparison to the rate of formation of new lac organisms and mutants among them. In fact, the rate of papilla development (growth of lac $^{+}$bacteria) is undoubtedly so fast in the region of exponential growth of the lac ${ }^{-}$microcolonies (Fig. 1) as to bring the calculation of minimum mutation rate very close to the true rate. It has not been possible to measure the actual rate of growth of lac ${ }^{+}$bacteria in papillae for technical reasons, but if it were 10 times as fast as the growth of the microcolony $(0.06 \mathrm{doubling} / \mathrm{hr}$.), an assumption that semi-quantitative observation indicates is quite possible, the minimum mutation rate calculated would be indistinguishable from the true rate. This approximation is also not affected by death of bacteria in the central non-growing portion of the colony, for total and viable counts of the number of bacteria in microcolonies are indistinguishable.

Another method of calculating the mutation rate in the presence of lactose involves the use of the data described in Fig. 2 (see p. 74). At the time of the last sampling of the cultures containing lactose some lac ${ }^{+}$bacteria were found to be present. If these bacteria are assumed to have been in the process of overgrowing their parental lac ${ }^{-}$population, which was in a stationary phase because of exhaustion of the carbon source, then it is possible to estimate the time of origin of the first $\mathrm{lac}^{+}$bacterium by assuming that it multiplied at the maximum rate the medium would allow ( 1.2 generations/hr.). (The rate of increase of at least some mutants in growing cultures of their parents seems to be almost exponential; Ryan \& Schneider, unpublished.) The number of lac bacteria present at the time of origin of the first lac ${ }^{+}$can be read directly from the growth curve and when divided by $\ln 2$ we obtain the number of bacterial generations after which the first mutation occurred. The chance of the mutation is the reciprocal of this, and in the case of the two experiments shown in Fig. 2 was $2 \cdot 4 \times 10^{-7}$ and $2 \cdot 8 \times 10^{-7} /$ bacterium/generation. These figures are good approximations of the result obtained by the papilla method. 
The chance of appearance of a $\mathrm{lac}^{+}$bacterium in the absence of lactose can be determined by using one of a number of methods, the most convenient of which for our purposes is the median method of Lea \& Coulson (1949). This involves finding the median number of new types in a series of similar cultures begun with a very small number of the parental type. For this purpose, in two experiments about $1000 \mathrm{lac}^{-}$bacteria were inoculated into $10 \mathrm{ml}$. medium containing a limiting amount of maltose. Fifty-four $0.1 \mathrm{ml}$. samples were then distributed to small test-tubes which were incubated in a moist chamber. After growth was complete the contents were removed with a pipette, and tubes were rinsed twice with $0.1 \mathrm{ml}$. lots of water. The contents of four of the tubes were diluted and plated in maltose agar to determine the total bacterial number. The whole contents of the remaining fifty tubes were spread on the surface of lactose agar to determine the number of $\operatorname{lac}^{+}$bacteria. The results in Table 6 show that in the absence of lactose the chance of appearance of lac ${ }^{+}$ bacteria per lac ${ }^{-}$bacterium per generation is about $2 \cdot 6 \times 10^{-7}$. This rate is indistinguishable from that observed in the presence of lactose.

Table 6. Variance analysis of the numbers of lac ${ }^{+}$mutants in different cultures in the absence of lactose

\begin{tabular}{|c|c|c|c|c|c|c|}
\hline $\begin{array}{l}\text { Concentration } \\
\text { of } \\
\text { maltose } \\
\text { (M) }\end{array}$ & $\begin{array}{c}\text { Total } \\
\text { no. of } \\
\text { bacteria/ } \\
0.1 \mathrm{ml} .\end{array}$ & $\begin{array}{l}\text { Median } \\
\text { no. of } \\
\text { lac }^{+} \\
\text {bacteria }\end{array}$ & $\begin{array}{c}\text { Chance of } \\
\text { mutation/lac } \\
\text { bacterium/ } \\
\text { generation }\end{array}$ & $\begin{array}{c}\text { Mean } \\
\text { no. of } \\
\text { lac }^{+} \\
\text {bacteria }\end{array}$ & $\begin{array}{l}\text { Variance } \\
\text { of the } \\
\text { mean }\end{array}$ & $\begin{array}{l}\text { Probability } \\
\text { that the } \\
\text { sample was } \\
\text { from a } \\
\text { homogeneous } \\
\text { population } \\
\text { of cultures }\end{array}$ \\
\hline $5.6 \times 10^{-4}$ & $3 \cdot 1 \times 10^{7}$ & $38 \cdot 5$ & $2.1 \times 10^{-7}$ & 55 & 2597 & $<0.01$ \\
\hline $5.6 \times 10^{-4}$ & $3.4 \times 10^{7}$ & 45 & $2 \cdot 7 \times 10^{-7}$ & 54 & 5510 & $<0.01$ \\
\hline $1.8 \times 10^{-4}$ & $1.3 \times 10^{7}$ & $12 \cdot 5$ & $2.5 \times 10^{-7}$ & 24 & 2386 & $<0.01$ \\
\hline $1.4 \times 10^{-3}$ & $0.9 \times 10^{-8}$ & 0 & $3 \cdot 2 \times 10^{-7}$ & 0.9 & $2 \cdot 6$ & $<0.01$ \\
\hline
\end{tabular}

\section{Variance analysis of the numbers of lac ${ }^{+}$bacteria appearing in different cultures in the absence of lactose}

It might be argued that the reason a lac $^{+}$bacterium has the same chance of appearing in the presence or in the absence of lactose is the fact that the mutants presumed to have been formed in maltose medium were counted after growing on plates in the presence of lactose. To test this a variance analysis of the data was made as suggested by Luria \& Delbrück (1943). Table 6 shows that the probability that the cultures utilized came from a homogeneous population of cultures is extremely small.

In contrast with the observed results the notion that exposure to the lactose in the testing plates induces the formation of $\mathrm{lac}^{+}$bacteria demands that cultures of lac bacteria growing in maltose be homogeneous with regard to their ability to respond to lactose. Jackson \& Hinshelwood (1949) offered a reason why cultures homogeneous in this regard would appear to be heterogeneous when plated on a testing agar. Their argument assumes that upon plating lac $^{-}$bacteria on lactose rapid death occurs among those that have not responded to lactose by becoming $\operatorname{lac}^{+}$. The rate at which death occurs is assumed to be a function of the length of time in which the culture has been 
in the stationary phase before plating, and it would be expected that this would vary somewhat from culture to culture. Such a possibility does not exist in these experiments, for not only does the number of lac and lac ${ }^{-}$ bacteria remain constant for more than $24 \mathrm{hr}$. in lac ${ }^{-}$cultures whose growth has ceased in limiting amounts of maltose, but each lac ${ }^{-}$bacterium plated on lactose agar, rather than dying, survives and forms a microcolony.

Nor is it probable that the observed variation was introduced by fluctuation in the manipulations employed in the variance analysis experiment (Eriksen, 1949). In the course of incubation the cultures lost an average of only $8 \%$ $(\sigma=6 \%)$ of their weight. In order to test whether the procedure employed removed all the bacteria in the small cultures the following experiment was performed. Twenty-five $0.1 \mathrm{ml}$. lots of medium, each containing about $\mathbf{2 5}$ bacteria, were pipetted into tubes from which they were immediately washed out by the usual procedure. Twenty-five other samples were plated directly from the source as a control. Both series were homogeneous by $\chi^{2}$ test $(\boldsymbol{P}=\mathbf{0} \cdot \mathbf{7}$ and $\mathbf{0} \cdot \mathbf{2}$ respectively) thereby confirming the accuracy of pipetting $0.1 \mathrm{ml}$. lots of medium. The means were 25 and 27 , showing a difference that is not significant $(t=\mathbf{1} \cdot \mathbf{4}, \boldsymbol{P}=\mathbf{0} \cdot \mathbf{2})$ and proving that essentially all of the culture was washed out. Furthermore, the spreading procedure used for the detection of lac ${ }^{+}$bacteria did not result in an appreciable loss of bacteria as was shown by plating 10 cultures containing about 70 bacteria on the surface of agar and 10 cultures directly in agar. In the former case the average number of colonies was 69 , while an average of 72 was obtained in the latter case. Once again the difference was not significant $(t=0 \cdot 87, P=0 \cdot 4)$. The counts of the total number of bacteria in the $0.1 \mathrm{ml}$. cultures showed a small variation, $\sigma$ never exceeding $25 \%$. As already mentioned, the method of enumerating lac $^{+}$bacteria showed upon test a variance not unexpected in terms of normal sampling error.

The most likely reason for the heterogeneity in numbers of $\mathrm{Iac}^{+}$bacteria among different cultures is that, if mutations have a fixed chance of occurring during growth in the absence of lactose, some will occur earlier than others and be the origin of greater numbers of mutants. If this be true the distribution of mutant numbers should not only have a large variance but it should have the specific form of the distribution calculated by Lea \& Coulson (1949). The data from the experiments reported in Table 6 fit very well the theory of Lea \& Coulson. Fig. 3 shows a comparison of the observed and theoretical distributions of the number of lac $^{+}$mutants in different cultures containing $5 \cdot 6 \times 10^{-4} \mathrm{M}$ lactose. The probability that the two distributions come from a homogeneous population is $\mathbf{0} \cdot \mathbf{2}$. Similar results were obtained with smaller populations grown on $1 \cdot 8 \times 10^{-4}(P=0 \cdot 3)$ and $1 \cdot 4 \times 10^{-3}(P=0 \cdot 3)$ x maltose. Since this distribution has a unique form it is quite unlikely that the fit is coincidental. Rather, the good correspondence can be taken to provide a final demonstration that the $\mathrm{lac}^{+}$bacteria found on the lactose agar plates arose at random during the growth of their lac $\mathrm{lar}^{-}$parents in maltose and did not arise on the lactose agar plates. Hence, the agreement between mutation rates in the presence and absence of lactose establishes the fact that the lac ${ }^{-}$to $\mathrm{lac}^{+}$ mutation is independent of this sugar. 
The extent to which the lac ${ }^{-}$gene is independent of its chemical environment in mutating to the lac ${ }^{+}$condition

Since it is conceivable that, despite independence of lactose, mutation of the $\mathrm{lac}^{-}$gene may be dependent upon one or another related compounds, several substances were tested by the methods already described. The first involved the use of $\mathrm{lac}^{-} t^{-}$bacteria in liquid medium and on the surface of agar. It was

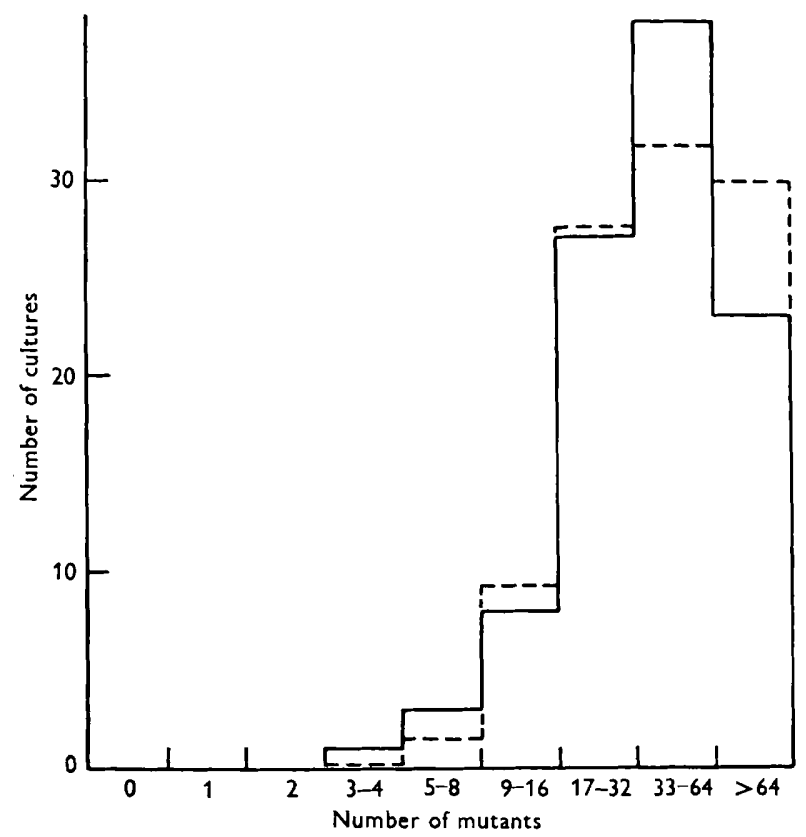

Fig. 3. The distribution of $\mathrm{lac}^{+}$mutants in strain ML $3 a$ of Esch. coli. The solid line represents the observed distribution; the dotted line the theoretical distribution calculated according to Lea \& Coulson (1949) on the basis of an average number of mutations determined from the median of the observed distribution.

at the same time possible to test mutation in the reverse direction by the use of lac $^{+} \mathrm{t}^{-}$. Table 7 summarizes the results obtained. Sporadic and limited growth of the sort shown in Table 3 occurred, but there was no evidence of an augmentation of mutant frequency. Among the $\operatorname{lac}^{-} \mathrm{t}^{-}$bacteria no $\mathrm{lac}^{+}$ mutants were evident, while the single lac ${ }^{-}$mutant found among the lac ${ }^{+} t^{-}$ parents in the presence of galactose may well be of spontaneous origin.

The same substances were also tested for their effect upon the rate of mutation in microcolonies but, as is shown in Table 8 , there is no significant difference between the rate of mutation in their presence and in their absence. Both of the above methods were chosen as affording the least opportunity for irrelevant selection phenomena to obscure the results. Hence, in terms of mutability the lac ${ }^{-}$locus appears to be extremely insulated from its chemical environment. 
Table 7. The numbers of bacteria tested for a modified genotype in the presence of a variety of compounds in liquid medium and on the surface of agar

\begin{tabular}{|c|c|c|c|c|c|}
\hline \multirow[b]{2}{*}{$\begin{array}{l}\text { Substance } \\
\text { added }\end{array}$} & \multirow[b]{2}{*}{$\begin{array}{l}\text { Concentration } \\
\text { (M) }\end{array}$} & \multicolumn{2}{|c|}{ Strain $\operatorname{lac}^{-} \mathrm{t}^{-}$} & \multicolumn{2}{|c|}{ Strain $\operatorname{lac}^{+} t^{-}$} \\
\hline & & $\begin{array}{c}\text { No. of } \\
\text { bacteria } \\
\text { examined }\end{array}$ & $\begin{array}{c}\text { Mutant } \\
\text { frequency } \\
\text { unlikely } \\
\text { to be } \\
\text { more than* }\end{array}$ & $\begin{array}{c}\text { No. of } \\
\text { bacteria } \\
\text { examined }\end{array}$ & $\begin{array}{l}\text { Mutant } \\
\text { frequency } \\
\text { unlikely } \\
\text { to be } \\
\text { more than* }\end{array}$ \\
\hline Lactose & $\begin{array}{l}1.6 \times 10^{-3} \\
1.6 \times 10^{-6}\end{array}$ & $\begin{array}{r}4572 \\
10636\end{array}$ & $\begin{array}{l}2 \times 10^{-4} \\
1 \times 10^{-4}\end{array}$ & $\begin{array}{l}1377 \\
2450\end{array}$ & $\begin{array}{l}7 \times 10^{-4} \\
4 \times 10^{-4}\end{array}$ \\
\hline D-Galactose & $\begin{array}{l}3.2 \times 10^{-3} \\
3.2 \times 10^{-6}\end{array}$ & $\begin{array}{l}2902 \\
8581\end{array}$ & $\begin{array}{l}3 \times 10^{-4} \\
1 \times 10^{-4}\end{array}$ & $\begin{array}{l}2784 \dagger \\
4285\end{array}$ & $\begin{array}{l}4 \times 10^{-4} \\
2 \times 10^{-4}\end{array}$ \\
\hline $\begin{array}{l}\text { Phenyl- } \beta \text {-D-thio- } \\
\text { galactoside }\end{array}$ & $\begin{array}{l}1.0 \times 10^{-3} \\
1.0 \times 10^{-6}\end{array}$ & $\begin{array}{l}1566 \\
649.4\end{array}$ & $\begin{array}{l}6 \times 10^{-4} \\
2 \times 10^{-4}\end{array}$ & $\begin{array}{l}1648 \\
6763\end{array}$ & $\begin{array}{l}6 \times 10^{-4} \\
1 \times 10^{-4}\end{array}$ \\
\hline $\begin{array}{l}\text { Methyl- } \beta \text {-D-galacto- } \\
\text { side }\end{array}$ & $1.5 \times 10^{-4}$ & 2224 & $5 \times 10^{-4}$ & 2344 & $4 \times 10^{-4}$ \\
\hline Melibiose & $1.5 \times 10^{-4}$ & 2609 & $4 \times 10^{-4}$ & 2165 & $5 \times 10^{-4}$ \\
\hline D-Fucose & $3.0 \times 10^{-3}$ & 2019 & $5 \times 10^{-4}$ & 2538 & $4 \times 10^{-4}$ \\
\hline $\begin{array}{l}\text { L-Sorbose } \\
\text { Nil }\end{array}$ & $\begin{array}{c}2 \cdot 8 \times 10^{-3} \\
-\end{array}$ & $\begin{array}{l}1324 \\
8120\end{array}$ & $\begin{array}{l}8 \times 10^{-4} \\
1 \times 10^{-4}\end{array}$ & $\begin{array}{l}1204 \\
6098\end{array}$ & $\begin{array}{l}8 \times 10^{-4} \\
2 \times 10^{-4}\end{array}$ \\
\hline
\end{tabular}

* Approximate reciprocal of previous column.

$\dagger$ One lac $^{-}$mutant found; in no other experiment were any mutants found.

Table 8. Mutation rates to $\mathrm{lac}^{+}$in microcolonies grown on agar in the presence of lactose and other compounds

\section{Concentration of lactose}

(M)

$\mathbf{3} \times 10^{-5}$

$3 \times 10^{-5}$

$3 \times 10^{-5}$

$3 \times 10^{-5}$

$1.3 \times 10^{-4}$

$1.3 \times 10^{-4}$

$1.3 \times 10^{-4}$

$1.3 \times 10^{-4}$

$1.3 \times 10^{-4}$

$\quad \begin{aligned} & \text { Substance } \\ & \text { added }\end{aligned}$
D-Galactose
D-Galactose
D-Galactose
D-Galactose
Phenyl- $\beta$-D-thio-
galactoside
Methyl- $\beta$-D-galactoside
Melibiose
D-Fucose
L-Sorbose

Concentration

$3.2 \times 10^{-3}$

$3 \cdot 2 \times 10^{-4}$

$3.2 \times 10^{-5}$

$3 \cdot 2 \times 10^{-6}$

$1 \times 10^{-3}$

$1.5 \times 10^{-4}$

$1 \times 10^{-3}$

$1.5 \times 10^{-3}$

$1.4 \times 10^{-3}$
Chance of mutation/bacterium/ generation

$0.64 \times 10^{-7 *}$ $\mathbf{2 \cdot 6 0} \times 10^{-7}$ $0.97 \times 10^{-7}$ $0.73 \times 10^{-7}$ $1.4 \times 10^{-7}$

$1.9 \times 10^{-7}$ $1.3 \times 10^{-7}$ $1.1 \times 10^{-7}$ $0.77 \times 10^{-7}$

* $0.49 \times 10^{-7}$ by Poisson method, $0.78 \times 10^{-7}$ by count of the number of papillae.

\section{DISCUSSION}

The case of the adaptation of lac $^{-}$bacteria to use lactose is instructive, inasmuch as the complete expression of the mutation involves both the development of an enzyme in response to a substrate and the selective overgrowth of a mutant able to form this enzyme. The mutation to the lac ${ }^{+}$ condition occurs independently of lactose in a random fashion and simply confers the capacity to respond to lactose by the adaptive formation of lactase. In the absence of lactose competent lac ${ }^{+}$organisms cannot be distinguished from $\mathrm{lac}^{-}$; both possess the same basal amount of $\beta$-galactosidase. When lactose is present, on the other hand, the rare $\mathrm{lac}^{+}$bacteria can complete the 
adaptive response by developing lactase and using the substrate. As a result the lac $^{+}$bacteria have a selective advantage and overgrow their parental lac ${ }^{-}$ bacteria, bringing about a heritable change in the population. A mutation rate of the magnitude found in the absence of lactose allows the calculation of exactly the amount of overgrowth of lac ${ }^{+}$bacteria found in the experiments referred to in Fig. 2. Where mutations result in the capacity to form enzymes that are not adaptive, adaptations take place by selection without the substrate (or its absence) provoking either the adapted genotype or the phenotype it allows. In this case the environment acts solely as a selective agent (Ryan \& Schneider, 1949; Fildes \& Whitaker, 1948).

Hinshelwood (1950), in his theory of bacterial adaptation, has failed to assess the role which the origin of genetic competence plays in this phenomenon. By the use of physical chemical models he has elaborated systems in which enzyme concentrations vary in accordance with the chemical environment and has proposed that such systems account for bacterial adaptation. Following Hinshelwood's line of interpretation, the enzyme, lactase, would be expected to increase autocatalytically in individual lac $^{-}$bacteria due to the presence of the substrate, lactose, and the bacterial population would by this means be transformed into the $\mathrm{lac}^{+}$condition. The error here lies in the failure to recognize the nature of the genetic difference between $\mathrm{lac}^{+}$and $\mathrm{lac}^{--}$bacteria and the random character of its origin.

There is no question about the existence of adaptively formed enzymes, but we may ask whether there is evidence that inherited adaptations are ever brought about by the mechanism proposed by Hinshelwood. The publications of Hinshelwood and his school on this problem are so numerous as to preclude any detailed assessment in this discussion. However, it is possible to evaluate the arguments against the mutational origin of adaptation that they have used in their work. These have conveniently been summarized by Hinshelwood (1950).

The first objection refers to the conclusions that have been drawn by others from variance analyses of the numbers of mutants in different cultures. Hinshelwood has suggested that the results may not be in agreement with the hypothesis of induced change for reasons other than that they were brought about by random mutations. This is a legitimate objection but cannot apply to the present case for the reason that there is an exact quantitative agreement between the actual distribution of mutants and that predicted by random mutation. This distribution is not expected by any alternative hypothesis thus far proposed. For the same reason the objection is not valid in the case of a number of other adaptations. In several instances, however, the observed and theoretical distributions are not in accord, but even in these cases the reason for the disagreement may be consistent with the mutation hypothesis (Ryan, 1952). Furthermore, the specific, non-mutational interpretations that have been offered by Jackson \& Hinshelwood (1949) and by Eriksen (1949) to account for the extremely large variance found in mutant distributions have been shown in the present case to be inapplicable. As a consequence, it can be concluded that where variance analyses have been properly carried out 
the evidence has been in accord with the hypothesis of mutation and is inconsistent with the notion of adaptively induced change.

The remaining objections to the mutation hypothesis arise especially from the findings of Hinshelwood's school (sce Dean \& Hinshelwood, 1951). In the first place they frequently found that very small inocula adapt and consequently concluded that all of the bacteria introduced into the new environment must be involved in the change. A similar conclusion was drawn by Virtanen (1948) who observed that every organism of Esch. coli plated on the surface of agar adapted to use lactose. In both of these cases it is necessary to determine whether the responsible factor might have been the slow, background growth of parental types which resulted in the formation of mutants that were selected for. Jackson \& Hinshelwood (1949), for example, studying the adaptation of Esch. coli to use lactose, reported that agar and silica gel, to which no carbon source had been added, supported the slow growth of colonies. This fact, which we have confirmed, serves to invalidate their conclusion that the adaptation did not involve mutation. Where background growth cannot be avoided its effect must be estimated before a statement can be made as to whether or not each of the original bacteria becomes adapted.

Another argument against the mutation hypothesis involves the fact that, if mutation is the basis of the adaptation being studied, forward and back mutation rates (in addition to whatever specific selection operates for or against the mutant) should eventually bring about an equilibrium in a population growing in the absence of the substance with which the adaptation is concerned. Hinshelwood \& Jackson (1950) found that the serial transfer of Aerobacter aerogenes in various media did not decrease the lag period required for growth on $\mathrm{D}$-arabinose. It was concluded that the populations must have been at equilibrium with regard to the proportion of arabinose positive mutants (which exhibit a very short lag period on arabinose). The equilibrium frequency of arabinose-adapted organisms was calculated to be about $10^{-7}$, indicating that the rate of mutation from ability to inability to use arabinose (or selection against arabinose positive organisms) must be rather high. Nevertheless, when arabinose positive cultures were serially transferred in the absence of arabinose they remained stable indefinitely. This evidence would seem to indicate that the mutation hypothesis cannot account for the behaviour of this bacterial system.

A similar result was observed in populations of Esch. coli mutating from L-histidine dependence to independence (Atwood, Schneider \& Ryan, 1951). The explanation was found, however, to be completely consistent with the mutation hypothesis. In the course of serial transfer, mutations to faster growing types appeared which had no relation to the mutation to histidine independence that was being studied. These fitter types overgrew the old population and eliminated not only the parental bacteria but also the mutants among them. Eventually among the fitter bacteria new mutants appeared but these too were eliminated when a further fitter type appeared in the culture. In this way, since periodic selection occurred frequently enough, the mutants were prevented from attaining true mutational equilibrium and a pseudo- 
equilibrium resulted in which mutant frequency was much lower. Since the mutation to faster growth almost invariably occurs in the major component of the population, periodic selection serves to stabilize that component during growth. Yet there is always present a small reserve of mutant organisms which can overgrow the population when the environment changes in their favour. This phenomenon appears to be general and, unless it is shown not to operate in a particular system, the failure of mutational equilibrium to be obtained cannot be used as evidence that mutation is not the basis of the change being observed.

Hinshelwood has placed much weight on the claim that the stability of an adaptation is a function of the 'thoroughness' of training. Incompletely trained organisms lose their adaptation upon removal from the medium to which they are adapted. But completely trained organisms, after long exposure to the medium in question, are stable when removed from it. This could be interpreted as due to the fact that incompletely trained cultures, although consisting mostly of mutants, still contained a few unadapted parental bacteria which overgrow when transferred to another medium. Cooke \& Hinshelwood (1947) (see also Pryce \& Hinshelwood, 1947) tested this possibility by reconstructing a mixture of $A$. aerogenes consisting of bacteria unable to utilize glycerol rapidly and stable organisms that had been completely 'trained' to use this substance by a large number of transfers in its presence. When this mixture was serially transferred on sugar it did not change to a glycerol non-utilizing condition, a fact that convinced the investigators that incompletely trained cultures could not consist of such mixtures. This conclusion does not necessarily follow since the adapted bacteria, obtained after many generations of training, might well have been faster growing types that came to predominate by a periodic selection of the sort described above. Although non-adapted bacteria may have a selective advantage over adapted bacteria of their own growth type they would not possess such an advantage over adapted bacteria of a fitter type. Reconstruction experiments of the sort performed by Cooke \& Hinshelwood can be instructive only when they involve components of the same growth type.

Finally Hinshelwood, calling attention to the fact that adaptations may be additive, contends that on the mutation hypothesis 'the role assigned to chance is a rather remarkable one'. Be that as it may, we should not fail to appreciate the powerful directive role of the environment, not in inducing mutations, but in determining their effect on the constitution of the population. This, together with a recognition of the pleomorphic effect of certain genes, might even lead one to anticipate more plasticity on the part of populations than has been hithertofore demonstrated.

The above considerations, taken in conjunction with those presented by Cavalli (1951) on bacterial adaptation to drug resistance, lead to the conclusion that no solid evidence for Hinshelwood's theory exists. This, of course, does not exclude the possibility that in some instances, when the proper experimental tests have been performed, his theory will provide the best interpretation. But, before it is accepted in any instance, modern genetic conceptions must be shown clearly not to apply. 
We are left then with the result that some adaptations, at least, originate in the form of random mutations. It is not so surprising that mutations, under constant environmental conditions, are distributed in time and in space at random. But one may wonder why, if a gene is a differentiated molecule (or part of a molecule), it has not been possible to cause it to react in a specific way and thereby mutate. Chemical mutagens are well known but they do not cause patterns of mutation different from those induced by irradiation (Tatum \& Perkins, 1950).

Compounds related to the activity of the $\mathrm{lac}^{+}$locus were chosen as possible mutagens for this study, on the working hypothesis that genes may not be unrelated in configuration to the enzymes whose synthesis they control, and hence may enter into similar chemical combinations (see, for example, Emerson, 1945).

The compounds used have been shown by Monod et al. (1951) to have certain relations to the activity of the lac ${ }^{+}$locus. Lactose, for example, can be used as a carbon source by $\mathrm{lac}^{+}$bacteria, is a good inducer of $\beta$-galactosidase in these organisms, and has a strong affinity for the enzyme in vitro. In the same strain, D-galactose is a moderate inducer of lactase and has a feeble affinity. Phenyl- $\beta$-D-thiogalactoside, on the other hand, although it is inactive as an inducer, has a strong affinity for the enzyme, acts as a competitive inhibitor of its activity and prevents the formation of the enzyme. In contrast, methyl- $\beta$-D-galactoside and melibiose are excellent inducers but have little or no enzyme affinity. Fucose (6-deoxygalactose), like the unrelated sugar, sorbose, neither induces nor has affinity. If a gene concerned with the synthesis of lactase possessed groups similar to those causing the affinity of lactase for some of the compounds tested, the combination of the gene with these substances would be expected to have modified its stability. Monod et al. (1951) showed that the act of induction does not involve the combination of the inducer, or a derivative of it, with the enzyme formed. If the act of induction involved a combination with the gene for reasons other than an affinity for lactase, some of these substances might have entered into such combinations. The fact that none of these compounds significantly altered genetic stability does not, however, provide a rigorous test of the hypothesis of the similarity between gene and enzyme. In the first place, the mutated $\mathrm{lac}^{-}$gene may not be able to enter into the same combinations as the lac ${ }^{+}$ gene so that only the experiments involving the detection of lac mutants among lac ${ }^{+}$parents may be relevant. This may be especially true if the lac strain is what it is because it possesses a suppressor mutation at some locus only indirectly concerned with lactase synthesis. Further, the similarity between gene and enzyme may not involve the groups with which the substances tested enter into combination. The negative results obtained should not preclude further examination of the notion. In any event the results would seem to indicate that the gene is not promiscuous in its combination with chemicals in its environment. 
This work was done while the author was on leave from the Department of Zoology, Columbia University, New York 27 and Fellow of the Guggenheim Foundation and of the United States Government under the Fulbright Act, 1950-1. The author wishes to express his gratitude to these organizations and to Dr André Lwoff and Dr Jacques Monod to whom he is indebted in innumerable ways.

\section{REFERENCES}

Atwood, K. C., Schnemer, L. K. \& Ryan, F. J. (1951). Periodic selection in Escherichia coli. Proc. nat. Acad. Sci., Wash. 37, 146.

BARER, G. R. (1950). The action of streptomycin on Bacterium lactis aerogenes. J. gen. Microbiol. 4, 1.

Cavalli, L. (1951). Genetical analysis of drug resistance. Symp. Int. Chim. Microbiol. Roma, no. 101.

Conn, M. \& Monow, J. (1951). Purification et propriétés de la $\beta$-galactosidase (lactase) d'Escherichia coli. Biochim. Biophys. Acta, 7, 153.

Cooke, E. G. \& Hinshelwood, C. N. (1947). The adaptation of Bacterium lactis aerogenes to glycerol and to various carbohydrates. Trans. Faraday Soc. 43, 733.

Dean, A. C. R. \& Hinshelwood, C. N. (1951). Induced and other variations in bacterial cultures. J. chem. Soc. p. 1157.

Emerson, S. (1945). Genetics as a tool for studying gene structure. Ann. Mo. bot. Gdn. 32, 243.

Eriksen, K. R. (1949). Studies on the mode of origin of penicillin resistant Staphylococci. Acta path. microbiol. scand. 26, 269.

Fildes, P. \& Whitaker, K. (1948). 'Training' or mutation of bacteria. Brit. J. exp. Path. 29, 240.

Hinshelwood, C. N. (1950). Chemistry and bacteria. Nature, Lond. 166, 1089.

Hinshelwood, C. N. \& J ACKson, S. (1950). The stability of D-arabinose adaptation of Bact. lactis aerogenes. Proc. Roy. Soc. B, 137, 88.

Jackson, S. \& Hinshelwood, C. N. (1949). An investigation of the nature of certain adaptive changes in bacteria. Proc. Roy. Soc. B, 136, 562.

LEA, D. E. \& Coclson, C. A. (1949). 'The distribution of the numbers of mutants in bacterial populations. J. Genet. 49, 264.

Luria, S. E. \& Delbrück, M. (1943). Mutations of bacteria from virus sensitivity to virus resistance. Genetics, 28, 491 .

Massini, R. (1907). Über einen in biologischer Beziehung interessanten Kolistamm (Bacterium coli mutabile). Arch. Hyg., Berl. 61, 250.

Monod, J. \& Auduread, A. (1946). Mutation et adaptation enzymatique chez Escherichia coli-mutabile. Ann. Inst. Pasteur, 72, 868.

Monod, J., Cohen-Bazire, G. \& Cohn, M. (1951). Sur la biosynthèse de la $\beta$-galactosidase (lactase) chez Escherichia coli. La specificité de l'induction. Biochim. Biophys. Acta, 7, 585.

MonoD, J. \& CoHn, M. (1952). La biosynthèse induite des enzymes (Adaptation enzymatique). Advances in Enzymology (in the Press).

Pryce, J. M. \& Hinshelwood, C. N. (1947). The adaptation of Bacterium lactis aerogenes to various inhibitors. Trans. Faraday Soc. 43, 742.

Ryan, F. J. (1952). The distribution of numbers of mutant bacteria in replicate cultures. Nature, Lond. 169, 882.

Ryan, F. J. \& Schnemder, L. K. (1949). The consequences of mutation during the growth of biochemical mutants of Escherichia coli. IV. The mechanism of inhibition of histidine independent bacteria by histidineless bacteria. $J$. Bact. 58, 201.

Tatum, E. L. \& Perkins, D. D. (1950). Genetics of microorganisms. Ann. Rev. Microbiol. 4, 129.

Virtanen, A. I. (1948). Adaptive formation of enzymes. Svensk kem. Tidskr. 60. 23.

(Received 30 January 1952) 